\title{
Suomen arkkitehtuurin historia täydentyy
}

Susanna Aaltonen

Netta Böök, Kari Immonen, toim. \& Aino Niskanen, arkkitehtuurin historian asiantuntijatoim. sekä Laura Berger, kuvatoim.: Uno Ullberg. Viipurin arkkitehti (Arkkitehtuurimuseo, 2020), 417 sivua. Kirjoittajat: Anna Autio, Laura Berger, Igor Borisov, Netta Böök, Viktor Dmitrijev, Maarit Henttonen, Kari Immonen, Olli Immonen, Timo Keinänen, Marja Terttu Knapas, Julia Kripatova, Liisa Lindgren, Irma Lounatvuori, Anastasia Martynova, Julia Moshnik, Petri Neuvonen, Aino Niskanen, Riitta Niskanen, Katariina Ockenström, Simo Paavilainen, Lauri Putkonen, Tuula Pöyhiä, Kimmo Sarje, Pirkko-Liisa Schulman, Elina Standertskjöld, Hannes Teräsvuori.

Suomen arkkitehtuurihistorian kaanoniin on komealla ja painavalla tavalla lisätty arkkitehti Uno Ullberg (1879-1944). Ahkerasta ja aikaansaavasta arkkiteh-

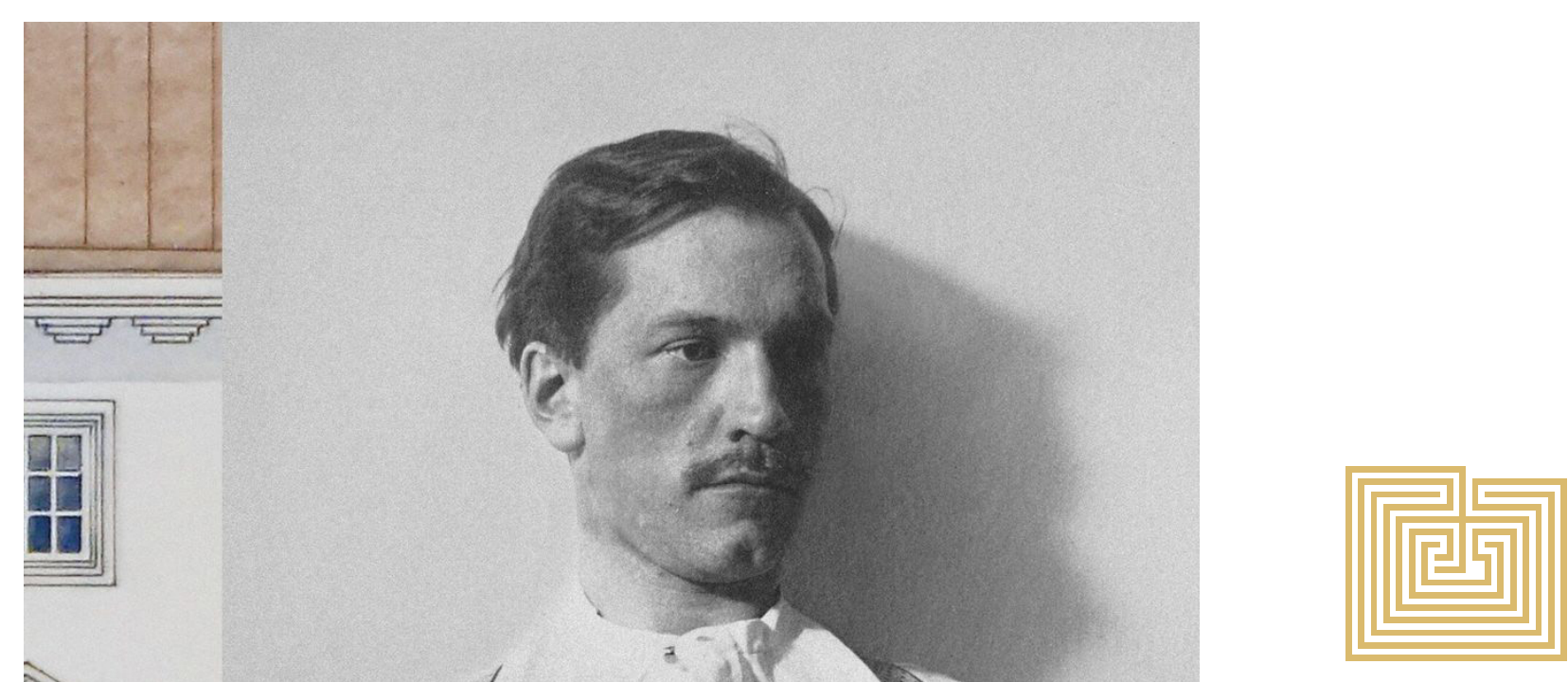


dista on tehty kohteensa näköinen huolellisesti toimitettu ja tutkimuksellisesti runsas ja esikuvallinen teos. Kirjahanketta varten perustetun Uno Ullberg -seuran ja Arkkitehtuurimuseon julkaisema yli 400-sivuinen monografia muistuttaa hyvällä tavalla myös siitä, että arkkitehtuuritutkimuksen saralla on vielä runsaasti tehtävää ja kiinnostavia aukkopaikkoja täydennettävinä.

Teoksen nimi Viipurin arkkitehti on osuva. Uno Ullberg vaikutti merkittävästi Viipurin kaupungin muotoutumiseen 1910-luvulta 1940-luvulle. Hän perusti syntymäkaupunkiinsa arkkitehtitoimiston vuonna 1906(-1909) yhdessä opiskelukollegansa arkkitehti Axel Gyldénin kanssa, jatkoi sitten vuodesta 1910 alkaen omassa toimistossaan ja toimi Viipurin kaupunginarkkitehtina vuosina 1932-1936. Vuosikymmenten työn tuloksena Viipuriin toteutettiin kaupunkikuvallisesti tärkeitä ja näkyviä rakennuksia, kuten: Kauppahalli (1908, purettu) Pyöreän tornin uudistus sisustuksineen (1922-23) Pamppalan talo (1923-24), Viipurin Panttilaitos (1931), Viipurin taidemuseo ja piirustuskoulu (1928-1930), Viipurin maakunta-arkisto (1932-33) ja Viipurin naistensairaala (1936-37).

Aikalaiset ymmärsivät arvostaa Ullbergin työtä: "Viipuri voi onnitella itseään, että sillä on taiteilija, joka näin pieteetillä ja taiteellisesti restauroi ja kaunistaa kaupungin muinaismuistoja" (s. 119 lainaus A. L. Weisenbergin kirjeestä Ullbergille 1924.) Kohteiden nykyinen tarkastelu nostaa esiin myös erittäin tärkeän ja akuutin kysymyksen Ullbergin kohteiden rakennussuojelusta. Viipurin rakennusten kohtalo tuodaan omana teemanaan esiin kirjan viimeisessä pääluvussa venäläisten asiantuntijoiden artikkelien kautta. Tämä on eittämättä Netta Böökin Karjalan-tuntemuksen ja venäjän kielen osaamisen ansiosta. Alvar Aallon Viipurin kirjaston tietävät kaikki. Nyt soisi, että myös Uno Ullbergin mittava elämäntyö Viipurissa saisi ansaitsemansa kohtelun ja muun muassa kulttuuri- ja arkkitehtuurihistoriallisesti arvokkaan Viipurin taidemuseon rakennussuojeluun panostettaisiin. Tätä varten teoksen osittainenkin toimittaminen myös venäjänkielisenä olisi erittäin perusteltua.

Kirjan lähdemateriaali on kunnioitusta herättävän kattavaa. Suurta aineistoa on myös hyödynnetty tarkasti ja yksityiskohtaisesti. Arkkitehdin työstä kertovat dokumentit käsitellään seikkaperäisesti: toteutumattomat ja toteutuneet suunnitelmat lukuisine piirrosluonnoksineen ja rakennetut rakennukset, niiden moninaiset vaiheet, vastaanotto, käyttö ja kohtalo hyvin säilyneistä raunioituneisiin, tärveltyihin ja kokonaan tuhottuihin. Lukijalle välittyy antoisalla tavalla sekä Uno Ullbergin henkilökohtaiset saavutukset että arkkitehdin työn luonne yleisellä tasolla.

Uno Ullberg oli ennen kaikkea aikaansa seuraava ja uusiutumiskykyinen arkkitehti. Nykyään kai puhuttaisiin resilienssistä, kyvystä joustaa erilaisissa tilanteissa. Tämä joustavuus näkyi niin Uno Ullbergin työurassa kuin henkilökohtaisessa elämässä, jossa ensimmäisen puolison Maiju Rannan varhainen kuolema vuonna 1917 loi varjon Ullbergin elämään. Uuttera työnteko jatkui vastoinkäymisistä huolimatta äkilliseen sairastumiseen ja kuolemaan vuonna 1944. Viimeisimpinä työnä pöydälle jäi Helsingin Lastenklinikka, joka valmistui 1945.

Ullbergin ammatillinen vahvuus näyttää ilmenneen kykynä omaksua ja soveltaa kansainvälisiä esikuvia, huomioida kollegoilta saamiaan virikkeitä kulloiseenkin kohteeseen eläytyen. Omalla tavallaan hienostuneesti Ullberg otti haltuun erilaisia paikkoja, tiloja ja suunnittelutehtäviä, kaupunkien asemakaavoista kaakeliuuneihin. Uusiutumiskyky ja hienostuneisuus ovatkin kirjoittajien usein käyttämiä sanoja. Ullberg hallitsi suvereenisti erilaiset rakennustyypit: koulut, kirkot, teollisuus- ja liikerakennukset, sairaalat ja asuintalot. Myös erilaisten rakennustekniikoiden hyödyntäminen ja kulloiseenkin kohteeseen sopivien materiaalien käyttö osoittavat Ullbergin hallinneen ammattinsa monipuolisesti. Ullbergin uran laaja-alaisuutta valotetaan lähes kaikista mahdollisista näkökulmista. Ainoastaan sisustukset jäävät hiukan vähemmälle huomiolla. Tyttären, sisustusarkkitehdiksi opiskelleen, mutta varhain kuolleen, Tuja Kirkkalan kautta ne olisivat kiinnostava lisäpohdinnan aihe.

Kirjan toimittajien, arkkitehti Netta Böökin ja emeritusprofessori Kari Immosen sekä koko työryhmän 
kunnianhimosta kertovat kirjaa varten kootut mittavat liitteet. Ullbergin työluettelo on pienimmät työt poisrajattuinakin kunnioitusta herättävä. Rakennusten kohdekartat, tiedot muuttuneista paikan- ja kadunnimistä lisäävät kirjan arvoa lähdeteoksena. Ullbergin curriculum vitae on toteutettu visuaalisesti kauniina aikajanana, johon on koottu yhdelle sivulle tiedot perhe-, opiskelu- ja virkavuosista sekä tärkeimpien rakennusten yms. tiedot ja vuodet.

Laura Bergerin kuvatoimitus ansaitsee erityismaininnan. Kuva-aineisto on häkellyttävän runsas: piirustuksia, aikalaisvalokuvia, postikortteja Ullbergin omasta albumista. Petri Neuvosen ottamat, tuoreet värivalokuvat on julkaistu ansaitsemassaan suuressa koossa. Salla Bedardin taitto on tyylikästä ja ilmavaa. Jotkut pohjapiirustuksista olisi ehkä voinut julkaista suurempina ja siten helpommin tarkasteltavina. Laajaan kuva-aineistoon ei sisälly vain Ullbergin kohteita. Kuvien avulla myös vertaillaan Ullbergin töitä aikakauden muiden arkkitehtien töihin. Se havainnollistaa tekstiä ja tukee tutkimusta syventäen Ullbergin töiden suhdetta aikaansa ja painottaen niiden merkitystä aikakautensa arkkitehtuuridiskurssissa.

Teoksen runsaudesta on vaikea ehdottaa turhien rönsyjen poistamista, sillä 27 kirjoittajan ja 49 artikkelin kokonaisuus toimii hyvin. Yksittäiset artikkelit ovat ansiokkaita ja esittelevät kaleidoskooppimaisesti kohdetta eri puolilta. Ullbergin työn kontekstualisointi syntyajankohtaansa ja paikkaansa sekä myös tutkimuksen nykykenttään onnistuu joitakin pieniä puutteita lukuun ottamatta erinomaisesti. Tekstien lyhyys ja luonne vaikuttavat siihen, etteivät ne aina johdattele tai ehdi syviin analyyseihin, mutta luonteva kokonaiskuva niistä rakentuu. Erikoisartikkelit puolustavat paikkaansa. Toimittajien Netta Böökin ja Kari Immosen esipuhe ja ensimmäinen artikkeli, "Uno Ullberg -kaikessa mukana" ja arkkitehtuuriprofessori Aino Niskasen yhteenvetoartikkeli Rajankävijä-luvussa ovat tietysti oleelliset valtavan materiaalin paketoinnin onnistumisessa. Näiden keskeisten tekstien avulla hahmotetaan artikkelien suhdetta toisiinsa ja luodaan kokonaisnäkemys Ullbergin arkkitehtuurin merkityksellisyydestä ja vaikutuksesta ennen ja nyt.

\section{Jatkopohdintoja}

Hyvin tehty tutkimus antaa aina ajattelemisen aihetta ja innostaa jatkotutkimukseen. Rikkaan lukukokemuksen jälkeen jää vielä miettimään arkkitehdin työtä, roolia ja vaikutusmahdollisuuksia yleisemminkin. Miten Ullbergin kohdalla näkyi arkkitehtuurin luonteeseen kuuluva ryhmätyö? Entä minkälainen rooli yksittäisellä arkkitehdilla oli uusien tuulien käyttöönotossa ja ideoiden levittämisessä? Entä miten voisi tarkemmin tarkastella esimerkiksi juuri Bauhausin vaikutusta ja kansainvälistä tyyliä (tyyli, jota Suomessa kutsuttiin funktionalismiksi) Ullbergin arkkitehtuurissa? Ja laajemmin voisi pohtia tutkimuksellista käännettä, jossa yksittäisen arkkitehdin uran sijaan katsottaisiin laajemmin arkkitehtuuria prosessina ja osana kulttuuria. ${ }^{1}$

Ullbergin työn kontekstualisointi Viipuriin on nähdäkseni juuri tällainen yritys tarkastella arkkitehtuuria prosessina, rakennuskulttuurin merkityksistä käsin. Kirjan luettuaan ymmärtää hyvin senkin, että otsikko "Viipurin arkkitehti" ei pysty tavoittamaan Ullbergin koko toiminta-aluetta tai ammattikuvaa. Kuten kirjassa tuodaan esille, Ullberg suunnitteli paljon muuallekin kuin Viipuriin, erityisesti Itä-Suomeen, Sortavalaan, Imatralle, ja Helsinkiin mm. Bensowin liiketalon ja Lastenklinikan sairaalan, jonka parissa Ullberg työskenteli Helsingissä viimeisinä työvuosinaan Lääkintöhallituksen yliarkkitehtina 1936-1944.

Bensowin liiketalo ja Lastenklinikan sairaala ovat esimerkkejä myös bauhaus-ideoiden -funktionalismin ja teknisten innovaatioiden - näkymisestä ja soveltamisesta Suomessa. Kuten Aino Niskanen yhteenvetoartikkelissaan kirjoittaa, Ullbergin kaikkein uudenmukaisimmat ideat näkyivät tuoreeltaan 1930-luvulta eteenpäin, erityisesti sairaala- ja linja-autoasemien suunnitelmissa. Aino Niskanen mainitsee vuonna 1941 valmistuneen Bensowin talon tekniset uutuudet Ullbergin itsensä esiin nostamina: sähköistys omine muuntajineen, koneellinen ilmanvaihto ja helposti vaihdettavat neonkilvet. Riitta Niskanen puolestaan tuo esille, että linja-autoasemat edustivat uutta, autoistuvan, modernin maailman rakennustyyppiä. Ullbergin 
suunnittelema vuonna 1935 valmistunut Sortavalan asema oli paitsi Sortavalan ensimmäinen funktionalistinen rakennus myös Suomen ensimmäinen funktionalistinen linja-autoasema. Bauhausiin esikuvana ja ilmiönä viittaa suoraan (s. 299) ainoastaan Maarit Henttonen, joka tulkitsee Lastenklinikan modernismia myös bauhaslaisten silmälasien läpi.

Modernismin näkökulmasta Ullbergin merkitys suomalaisen arkkitehtuurin kentällä on huomattava, siitäkin huolimatta, että Ullberg oli enemminkin soveltaja kuin innovaattori. Kirjan tuottama perustutkimus on tärkeä suomalaisen arkkitehtuurihistorian aukon täydentäjänä. Esipuheessa tavoitteeksi asetetaan Ullbergin asemoiminen pysyvästi arkkitehtuurihistorian kartalle. Tässä on onnistuttu erinomaisesti. Kansikuvaksi valittu valokuva Uno Ullbergista henkseleitään paukuttamassa kertoo, mistä kirjassa on kysymys: melko tuntemattomaksi jääneen arkkitehdin elämän ja työn yksiin kansiin kokoamisesta. Uno Ullberg ei korostanut itseään, mutta ansaitsee nyt saamansa huomion.
$1 \quad$ Ks. esim. Jessiaca Kelly \& Claire Jamieson, "Practice, Discourse and Experience: The Relationship Between Design History and Architectural History", Journal of Design History; Feb2020, Vol. 33 Issue 1: 1-15.
FT, dos. Susanna Aaltosen väitöskirja käsitteli suomalaista sisustusarkkitehtuuria. Hän on perehtynyt erityisesti muotoilun, mutta myös arkkitehtuurin historiaan. Aaltonen on opettanut taidehistoriaa Helsingin yliopistossa, Aalto-yliopistossa ja Avoimessa yliopistossa.

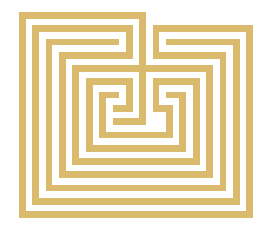

